\title{
Emotional Touch Points as a Predictor of Service Quality in a Tertiary Care Hospital, Chennai
}

\author{
Catakam Keshika, G. Jabarethina
}

\begin{abstract}
The Purpose of this study is to analyze the Impact of relationship between the Five Emotional Touch points experienced at a Tertiary Care Hospital and the dimensions of Service Quality delivered by a Healthcare Organization. The Emotional Touch Points experienced by In-Patients during their stay at a Tertiary Care Hospital is under the purview of this study. This study identifies and analyses the bottlenecks experienced by the In-patients emotionally which is considered as a major impact on the Quality of Service delivered by the Healthcare Organizations. The study design is a purely descriptive design about the quality of service delivered in the process of providing In-Patient health care services. The primary data were collected through closed ended questionnaire for assessing the emotional touch points and the dimensions of Service Quality rendered by the Hospital. The statistical tools used in this study are weighted mean, correlation and regression. The results revealed that the human element-empathy expressed by the Healthcare providers towards their patients is a highly significant dimension of Service Quality reflecting on the Emotional Engagement of patients with the Healthcare Organization..
\end{abstract}

Keywords : Emotional Touch points, Emotional Engagement, Patient Experience, Rational Satisfaction, and Service Quality.

\section{INTRODUCTION}

In this day and age, it's easy to take advantage of e-mails and other forms of virtual communication, but we don't forget the challenges the healthcare industry faces as it heads into the 21 st century - the missing element of the human touch. A customer meets the contact spot when he/she tries to buy product or services from the seller or service provider, which is called as touchpoint (Gaughran, 2017) .Using emotional touchpoints to help the patients to get positive care practice and develop the service. Kalaiselvi M (2014) stated in her article that Emotional touch points are measured using the parameters such as Truth Touch points , Purchase Touch points, Support and Hospitality Touch points, Environment Touch points and Post purchase Touch. Healthcare Organization's context of Service Quality is determined based on the level of Patient's Satisfaction and Patient's delight. The patient's perceived service quality can

Revised Manuscript Received on December 05, 2019.

* Correspondence Author

Catakam Keshika*, Quality Support Executive, Ibhar Healthcare Pastures Technology Alumnus, Faculty Of Management, Sri Ramachandra Institute Of Higher Education \& Research (Deemed To Be University) Porur, Chennai. Email: Ckeshika99@Gmail.Com Mobile: 9566208746

Dr.G.Jabarethina, Assistant Professor, Faculty Of Management, Sri Ramachandra Institute Of Higher Education \& Research, (Deemed To Be University) Porur, Chennai. Email: Jabarethina@Gmail.Com be interpreted from the differences between the direction and the degree of perception and expectations of the patients. The product of the efforts made by the healthcare providers in order to invest in meeting the patient's expectations reflects in the Quality of Service delivered by the Healthcare Organization. (Francis, 2012).

The service quality is determined by studying the dimensions such as: Reliability, Tangibles, Responsiveness, Empathy and Assurance (Parasuraman,1988).

\section{STUDY OBJECTIVES}

The study objective to explore the quality of service in terms of emotional touch points between the hospital and the patient, to evaluate the patients experience at various emotional touch points in a tertiary care hospital and to assess the impact of relationship between emotional touch points and service quality delivered by the healthcare organizations.

\section{LITERATURE REVIEW}

Emotional Touch Points experienced by patients in healthcare organizations and dimensions of service quality have an established relationship.

The Grönroos conceptualization, verifies and establishes a clear model of service-quality dimensions and empirically verifies the mediating role of overall relationship satisfaction in the formation of loyalty attributes and several important findings are reported. To gain Customer Loyalty by Relationship Marketing, verification is done by studying the effects of trust and commitment. (Ruben Chumpitaz Caceres, 2007). "Trust" is considered as a key factor by doctors in order to achieve the desired outcomes which will improve the relationship between physicians and patients (Mosadeghrad, 2014). Chang, Chen, \& Lan (2013) used Service Encounter Evaluation Model to measure how the service encounter processes affect customer satisfaction. The relationship between Purchase touchpoint, Support and Hospitality Touchpoints and Service Quality were established Factors like Service quality and Patient satisfaction, patients' perceptions of the professional's communication skill and attitude are positively influenced by Interpersonal- based medical service encounters in two ways : (A) There is a direct affect on patient satisfaction during the encounter of interpersonal-based medical service and (B) An indirect effect is represented by intervening variables namely service quality and patient trust which affect patient satisfaction.

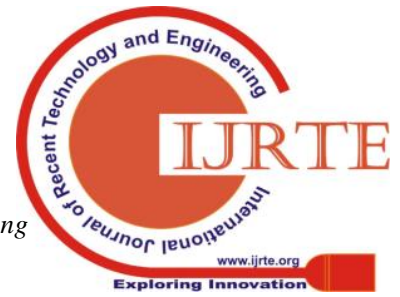


The lack of patient trust in medical doctors may be due to uncertainty and lack of familiarity of the medical practices which leads to repeated medical visits. This results in increased specialized healthcare, which is beyond the resources of healthcare organisations or even customers. The customers of healthcare organizations are concerned about the cost exceeding their financial capacity and their will to finance their own healthcare needs: Mosadeghrad (2014) stated that latest clinical guidelines and standards, with consistent, efficacious, effective and efficient healthcare services will satisfy the patients need and delight them in health care services. The five categories stated are: environment, empathy, efficiency, effectiveness and efficacy. They were grouped based on the 182 attributes of quality healthcare identified by him. He also identified that Quality healthcare includes characteristics such as availability, accessibility, affordability, acceptability, appropriateness, competency, timeliness, privacy, confidentiality, attentiveness, caring, responsiveness, accountability, accuracy, reliability, comprehensiveness, continuity, equity, amenities, and facilities.

\section{CONCEPTUAL FRAMEWORK AND HYPOTHESES}

The conceptual framework of this study was developed based on literatures. Figure 1 depicts the framework of the relationships between the factors of Emotional touchpoints (Douglas R. Conant, 2011; Kalaiselvi M, 2014) and Dimensions of Service Quality (Parasuraman, 1988).

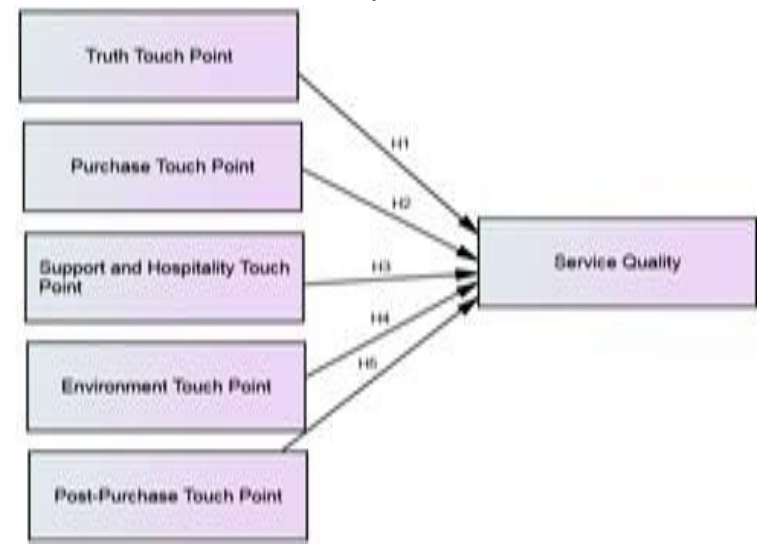

Figure - 1: The Conceptual framework of the study

The conceptual framework was test by using the following five hypotheses for measuring the relationship between the factors of Emotional Touch points and the Dimensions of Service Quality:

H1: Truth Touch Point has positive relationship with service quality

H2: Purchase Touch Point has positive relationship with service quality relationship with service quality

H4: Environment Touch Point has positive relationship with service quality

H5: Post-Purchase Touch Point has positive relationship
H3: Support and Hospitality Touch Point has positive

with service quality

\section{METHODOLOGY}

\section{A. Sample and Sampling Procedure}

In order to achieve the objectives of this study, convenience sampling is the type of sampling that is being used in this study. The researcher distributed 150 questionnaires among the Inpatients from Nephrology, Orthopedics, Oncology, Pediatrics, Obstetrics and Gynecology departments in a Tertiary Care Hospital at Chennai.

\section{B. Data Collection}

Structured questionnaires were used to collect data. The purpose of the study has been explained to the patients briefly while the study design is a purely descriptive design about the various emotional touch points in the process of health care services.

\section{Measurement}

Emotional touch points and dimensions of Service Quality were assessed by using a 5 point Likert scale and the respondents were asked to rate their level of satisfaction towards the quality of service rendered by the Tertiary Care hospital during the process of their treatment. Only four dimensions of Service Quality were included in this research. Tangibility was not considered as the outcome of emotional touchpoint in this study.

\section{RESULTS AND DISCUSSION}

\section{A. Profile of Respondents}

A total of 150 successfully completed questionnaires were used for analysis of data. The samples were composed of 52\% of Males and $48 \%$ Females. All of the Patients are Indian.

Table - 1: Demographic Analysis

\begin{tabular}{|c|c|c|}
\hline Demographics & $\begin{array}{c}\text { Number of } \\
\text { Respondents }\end{array}$ & Percentage \\
\hline Gender & & \\
\hline Male & 78 & 52 \\
\hline Female & 72 & 48 \\
\hline Age & & \\
\hline Less than 20 years & 29 & 12.33 \\
\hline 20 to 39 years & 61 & 40.6 \\
\hline 40 to 59 years & 13 & 31.33 \\
\hline 60 to 79 years & 0 & 8.67 \\
\hline Above 80 years & & 0 \\
\hline Frequency of visits & 4 & 2.67 \\
\hline Less than 1 time & 81 & 54 \\
\hline 1 to 3 times & 57 & 38 \\
\hline 3 to 5 times & & 5.33 \\
\hline More than 5 times & & \\
\hline Source: Primary Data & & \\
\hline
\end{tabular}

The Table 1 shows that In-patients under the age group of 20 to 39 years are 41

Published By:

Blue Eyes Intelligence Engineering 
$\%, 31 \%$ under the age group of $40-59$ years , $12 \%$ are less than 20 years and $8 \%$ of the In-patients were under the age group of 60-79 years.

In terms of Frequency of Visits , 54 per cent of the target In-patients have visited the hospital three times, while 2.67 per cent of the target In-patients have visited the hospital less than one time.

\section{B. Correlation Analysis}

The relationship between the Emotional touchpoints (Independent Variables) and the Dimensions of Service Quality (Dependent Variables) are measured by using correlation analysis. Table 2 Shows the tests results of all variables identified as Emotional touchpoints influencing the Patient's emotional engagement towards the Healthcare organization and its Quality of Service.

Table 2 : Relationship between dimensions of emotional touch points and service quality- Mean, SD and Correlation Analysis

\begin{tabular}{|c|c|c|c|c|c|c|c|c|c|c|c|c|}
\hline 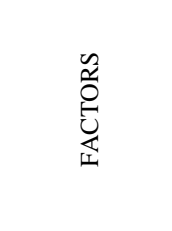 & 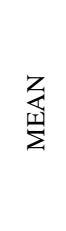 & के & $\hat{E}$ & 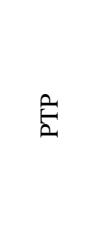 & 空 & 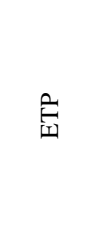 & $\begin{array}{l}\hat{\hat{2}} \\
\hat{\tilde{\Omega}}\end{array}$ & 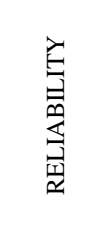 & 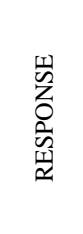 & 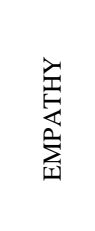 & 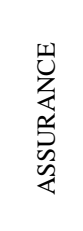 & 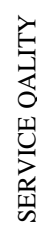 \\
\hline TTP & 3.41 & .300 & 1 & & & & & & & & & \\
\hline PTP & 3.96 & .243 & $.191 *$ & 1 & & & & & & & & \\
\hline SHTP & 3.54 & .256 & -.134 & .042 & 1 & & & & & & & \\
\hline ETP & 4.24 & .262 & -.026 & $.272 * *$ & -.074 & 1 & & & & & & \\
\hline РPТP & 3.48 & .263 & $.391 * *$ & .126 & .061 & -.108 & 1 & & & & & \\
\hline RELIABILITY & 3.14 & .348 & .018 & $.418 * *$ & $.224 * *$ & $.267 * *$ & -.061 & 1 & & & & \\
\hline RESPONSE & 3.32 & .535 & -.055 & -.103 & -.037 & .087 & -.157 & $-.242^{* *}$ & 1 & & & \\
\hline EMPATHY & 3.01 & .338 & $-.186^{*}$ & .085 & -.080 & .133 & $.247 * *$ & -.008 & .137 & 1 & & \\
\hline ASSURANCE & 2.88 & .400 & $-.383 * *$ & $-.184^{*}$ & -.071 & -.001 & $-.549 * *$ & -.071 & $.181^{*}$ & $-.242 * *$ & 1 & \\
\hline SQ & 3.09 & .199 & $-.301 * *$ & .058 & .003 & $.232 * *$ & $-.304 * *$ & .236 ** & $.717 * *$ & $.392 * *$ & $.491^{* *}$ & 1 \\
\hline
\end{tabular}

TTP- Truth Touch Point ; RTP - Response Touch Point; PTP - Purchase Touch Point

SHT- Support and Hospitality Touch Point ; ET- Environment Touch Point and PPT - Post Purchase Touch Point.

The Table 2 shows the result of weighted mean scores, which revealed that the respondents have agreed to all the factors related to emotional touch points and the highest means score are for environmental touch point $(4,24)$ and the lowest mean score for one of the dimensions of service quality namely Assurance(2.88). The Table 2 also revealed that the results are positive and the hypotheses 2,3 and 4 are accepted. H2: Purchase Touch Point has positive relationship with service quality $(\mathrm{r}=.058)$, which means that if the healthcare organization performs the promised service dependably and accurately toward the patient in terms of providing effective treatment and examining the communication skill of the consultant, it leads to a positive purchase touch point experienced by the patients hence the more the patients can rely on the services of Healthcare Organization.

H3:Support and Hospitality Touch Point has positive relationship with service quality $(\mathrm{r}=.003)$, which means that if the healthcare organization performs the promised service dependably and accurately in terms of explanation of the operation procedure (including the timely food service, clean rooms and toilets) to the patients and assessment of the standards in order to make interventions in the above areas, leads to a positive support and hospitality touch point experienced by the patients hence the more the patients can rely on the Healthcare Organization.

H4:Environment Touch Point has positive relationship with service quality $(\mathrm{r}=232 * *)$ which means that if the healthcare organization performs the promised service dependably and accurately in terms of identifying the safety and the privacy provided to the patients as well as the time spent with the doctors during their treatment in the hospital, therefore it leads to a positive environment touchpoint experienced by the patients, hence the more the patients can rely on the Healthcare Organization.

Hypotheses one and five are rejected due to negative results. H1: Truth Touch Point has negative 
relationship with service quality $(\mathrm{r}=-.301 * *)$ and $\mathrm{H} 5$ : Post-Purchase Touch Point has negative relationship with service quality ( $\mathrm{r}=-.304 * *)$.

The study was further tested with each dimension of REGRESSION ANALYSIS service quality and their relationship with each factor of emotional touch points in order to understand the real effect of relationship among the variables.

Table 3 Relationship between dimensions of emotional touch points and service quality-Regression Analysis

\begin{tabular}{|c|c|c|c|c|c|}
\hline \multirow{3}{*}{$\begin{array}{l}\text { EMOTIONAL TOUCH } \\
\text { POINTS }\end{array}$} & \multicolumn{5}{|c|}{ SERVICE QUALITY } \\
\hline & \multicolumn{2}{|c|}{ Unstandardized Coefficients } & \multirow{2}{*}{$\begin{array}{c}\text { Standardized Coefficients } \\
\text { Beta }\end{array}$} & \multirow{2}{*}{$\mathrm{t}$} & \multirow{2}{*}{$\mathrm{p}$-value } \\
\hline & B & Std. Error & & & \\
\hline (Constant) & 13.285 & 1.736 & & 7.651 & .000 \\
\hline TTP & -0.206 & 0.075 & -0.232 & -2.747 & $0.007 * *$ \\
\hline PTP & 0.070 & 0.066 & 0.085 & 1.052 & 0.294 \\
\hline SHTP & -0.005 & 0.060 & -0.007 & -0.084 & 0.933 \\
\hline ETP & 0.183 & 0.081 & 0.182 & 2.276 & $0.024 *$ \\
\hline PPTP & -0.158 & 0.063 & -0.208 & -2.496 & $0.014 *$ \\
\hline \multicolumn{6}{|l|}{$\mathrm{R}$ squared $=0.182$} \\
\hline \multicolumn{6}{|l|}{$\begin{array}{l}\text { F VALUE }=6.342 \\
\text { P VALUE } 0.000\end{array}$} \\
\hline $\begin{array}{l}\text { a. Dependent Variable: S } \\
\text { b. ** denotes significance } \\
\text { c. } * \text { denotes significance }\end{array}$ & $\begin{array}{l}\text { ality } \\
\text { el } \\
1\end{array}$ & & & & \\
\hline
\end{tabular}

The result of the table 3 shows that the independent variables of five emotional touch points namely Truth Touch Point (TTP), Response Touch Point (RTP), Purchase Touch Point (PTP), Support and Hospitality Touch Point (SHTP), Environment Touch Point (ETP) and Post Purchase Touch Point (PPTP) are not able to explain the variance of patients opinion on service quality. The R squared has explained the proportion of variance of a dependent variable that is explained by the independent variables in a regression model. The value of $\mathrm{R}$ - squared is $18 \%$, which is low fit measure for this study. The Table 3 reveals the predictive factor are significant only for three emotional touch points. Out of three, Environment Touch Point $\left(\left(\beta=.182, \mathrm{t}=2.276^{*}\right)\right.$ ranked first followed by Post Purchase Touch Point $(\beta=$ $\left.-.208, \mathrm{t}=--2.496^{*}\right)$ and Truth Touch Point $(\beta=-.232$, $\mathrm{t}=-2.747 * *)$. Thus, the insignificant $\mathrm{p}$ value indicates that Purchase Touch Point and Support and Hospitality Touch Point do not influence the Service Quality. Thus the multiple regression equation depicted as $\mathrm{Y}=13.285+-.206 \mathrm{X} 1$ $+.070 \mathrm{X} 2+-.005 \mathrm{X} 3+.183 \mathrm{X} 4+-.158 \mathrm{X} 5$ Where $\mathrm{Y}$ indicates Service Quality, X1 indicates TTP, X2 indicates PTP, X3 indicates SHTP, X4 indicates ETP, and X5 indicates PPTP. Here the coefficient of $\mathrm{X} 1$ is $-.206, \mathrm{X} 2$ is $.070, \mathrm{X} 3$ is -.005 , $\mathrm{X} 4$ is .183 and $\mathrm{X} 5$ is -.158 representing the partial effect of TTP, RTP, PTP, SHTP, ETP and PPTP when holding other variables as constant. The estimated negative sign indicates that when such effect is negative, then Service Quality value would decrease by every one unit of increase in Truth Touch point (-.206) at $1 \%$ level of significance, and Post Purchase Touch Point (-.158) at 5\% level of significant. The estimated positive sign indicates that Service Quality would increase by every one unit of increase in Environment Touch Point (.183) is significant at 5\% level. The result clearly shows that Environment Touch Point is constructively involved in the development of Service quality.

\section{DISCUSSIONS}

The findings of this study indicate Truth Touch point and Post-Purchase Touch point have a highly significant negative relationship with Service Quality. The further analysis on each dimension of service quality revealed that Reliability is significant and has a positive relationship with Purchase Touch point, Support and Hospitality Touch point, Environment Touch point while Empathy is highly significantly and is positively associated with post purchase touchpoint, This result emphasizes that the above stated purchase and environment touch points highly influence the patient's reliability on the healthcare organization and the empathy expressed towards the patients are important factors that determine the service quality delivered by the hospital. Service Quality can be improved by providing effective treatment and examining the communication skill of the consultant, explanation of the operation procedure (including the timely food service, clean rooms and toilets) to the patients and assessment of the standards in order to make interventions in the above areas, identifying the safety and the privacy provided to the patients as well as the time spent with the doctors during their treatment in the hospital and the individualized attention provided, engages the patients emotionally with the hospital due to level of satisfaction which in turn reflects on their reliability, loyalty towards the healthcare organization 
Furthermore, the findings of the study show that the Service Quality would increase by every one unit of increase in Environment Touch Point. When the safety and the privacy provided to the patients as well as the time spent with the doctors during their treatment in the hospital is made a high priority, the dimensions of service quality delivered by the healthcare organization increases. The result of this study indicates that the dimensions of Service Quality namely Reliability and Empathy of the Healthcare providers expressed toward their patients are highly dependent on the PTP, SHTP, PPTP and ETP whilst they are least dependent on TTP. Hence, the two dimensions reflect on the Patient's Emotional engagement with the healthcare providers to an extent where they are Loyal to the Healthcare Organization.

\section{MANAGERIAL IMPLICATIONS}

Based on this study, the main objective of the Healthcare organizations is to lay importance to the Emotional factors that reflect on Patient Satisfaction by solely training the healthcare providers on skills like emotional intelligence with the purpose to comply with the standardized care and understand the patients's expectations and sympathize in order to create an understanding of the patient's emotional touchpoints. PTP, SHTP and ETP are the emotional touchpoints that are in positive correlation with Reliability and Empathy and overall service quality. Therefore, within the Emotional Touchpoints context, it is strongly recommended to ensure that an emotionally satisfying safe and supportive environment must be created by focusing on the dependable and accurate promised services and the individualized attention provided by healthcare providers in order to enhance the dimensions of Service Quality as they are found to be highly correlated.

\section{CONCLUSION}

In today's world of Medical Advancements in Healthcare Technology, we are missing out on the Human Touch which plays a Key role in building relationships with the patients who are major stake holders of Healthcare Organizations. Adding Value to the Patient's experience includes enhancing the Transactional process that involves Emotional Touchpoints experienced during their time of stay at the Hospital. The Tertiary Care hospital, being the Area of study is one of the top most esteemed healthcare organization where patients experience several processes at the time of their stay namely, Administrative, Admission, Financial, Treatment and Diagnostic Processes.

This study Identifies and Analyses the Bottlenecks experienced by the In-patients emotionally which a major impact on the Quality of Service has delivered by the Healthcare Organizations. Hence Emphasis is laid upon the factors that influence the various touchpoints in order to create an (Emotional Engagement) affiliation, a sense of belonging of the stakeholders in order to improve the retention of patients for building the goodwill of the organization.

\section{REFERENCES}

1. Chang, C.S., Chen S.Y., and Lan Y.T. (2013). Service quality, trust and patient satisfaction in interpersonal-based medical service encounters. BMC Health Services Research, 13(1), 22.

2. Douglas R.Conant, M.N.(2011). TouchPoints: Creasting Powerful Leadership Connections in the Smallest of Moments. Jossey-Bass.

3. Gaughran and Kathy Roy (2017). Patient Experience Touchpoints: Doing the right things. Retrieved December 6, IBC, from https:// patientexperience.com/patient-experience-touchpoints/

4. GVKhyathi, S.T. (2019). An Empirical study to improve the Service Quality for Geriatric Patients in a Tertiary Care Hospital. Indian Journal of Public Health Research and Development, 10(1), 276-281.

5. Kalaiselvi M and Anantharajan D (2014). Analysis on Emotional Touch Points as a predictor of Service Qaulity in a Multispeciality Hospital, Chennai. International Research Journal of Business and Management, VII(8), 21-29.

6. Francis, A (2012). Service Quality. Retrieved February 26, IBC, from MBA knowledge base website: https://www/mbaknol.com/marketing-management/service-qality/\%0D

7. Mosadeghrad, A.M.(2014). Factors affecting medical service quality. Iranian Journal of Public Health, 43(2), 210-220.

8. Parasuraman, Zeithaml and Berry (1988). SERVQUAL: A Multiple-Item scale for measuring customer perceptions of service Qualitty. Journal of Retailing, 12-40.

9. RubenChumpitaz Caceres, N. Nicholas G. Papariodamis (2007). Service quality, relationship satisfaction, trust, commitment and business-to-business loyalty. European Journal of Marketing, 41(7/8), 836-867.

\section{AUTHORS PROFILE}

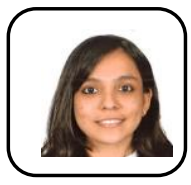

Catakam Keshika, has obtained her degree in B.B.A (Hospital \& Health Systems Management) (2016-2019) from Sri Ramachandra Institute for Higher Education and Research, Porur, Chennai. She was granted the Chancellor's Summer Fellowship at SRIHER, Porur. She has gained experience in the field of Service Quality by Interning at Organizations like Apollo Hospitals and ColumbiaAsia Hospitals. She has also gained knowledge about the Diagnostic and Point of Care Technologies by Hands-on Experience at Siemens Healthineers, Chennai and is currently pursuing her career in the field of Healthcare Quality working as a Healthcare Quality Support Executive at IBHAR Healthcare Technologies Pvt Ltd.

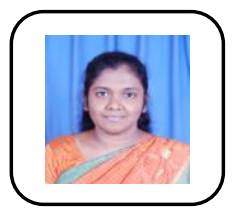

Dr. G. Jabarethina, obtained Ph.D degree in the discipline of Management Sciences after having completed M.Com., M.B.A., M.Phil., from University of Madras. She is also holding National Eligibility Test (NET) certificate in Management awarded by the UGC. She has been serving as a teaching faculty in Faculty of Management, Sri Ramachandra Institute of Higher Education and Research (Deemed to be University) since 2007, with her current designation being Assistant Professor. She has to her credit total of 18 years of teaching experience. Her current teaching interests include Accounting and Finance, Statistics, Human Resource Management and Research Methodology. She has guided more than Sixty (Mini \& Major) MBA projects and published 13 articles in Indexed journals. She has participated and presented 21 papers in the National and International conferences and received 5 best paper awards. She has genuine interest in research in the field of Management and Commerce. 